\title{
Multi-scale Web Mapping for Geoheritage Visualisation and Promotion
}

\author{
S. Martin • E. Reynard • R. Pellitero Ondicol • L. Ghiraldi
}

Received: 7 July 2012 / Accepted: 28 February 2014 / Published online: 20 March 2014

(C) The European Association for Conservation of the Geological Heritage 2014

\begin{abstract}
Due to the renewed interest for sites of geological interest, both in nature conservation and tourist sectors, numerous regional and national geosite inventories have been carried out in several countries during the last two decades. For this purpose, various assessment methods have been developed and published. The issue of the representation of the results of inventories - in particular, the mapping system, the question of updating data - remains open. Moreover, if in the field of nature conservation, practitioners are used to working with GIS, it is not the case in the tourist sector where data must be delivered to the users in open-access and easy-touse formats. This paper discusses what opportunities of web mapping methods and techniques there are in the domain of geoheritage assessment and promotion. A web mapping application in Google Maps application programming interface (API) framework is proposed to disseminate the results of geosite inventories carried out in Switzerland both at national and regional scales. The interest of the proposed application is discussed according to three main criteria: mapping interests and limitations, management purposes and interpretive issues.
\end{abstract}

\footnotetext{
S. Martin · E. Reynard $(\bowtie)$

Institute of Geography and Sustainability, Géopolis, University of Lausanne, 1015 Lausanne, Switzerland

e-mail: emmanuel.reynard@unil.ch

S. Martin

e-mail: simon.martin@bureau-relief.ch

R. Pellitero Ondicol

Department of Geography, University of Valladolid, Prado de la

Magdalena, 47011 Valladolid, Spain

e-mail: r.pellitero-ondicol@abdn.ac.uk

L. Ghiraldi

Regional Museum of Natural Sciences, via Giolitti 36, 10100 Torino, Italy

e-mail: luca.ghiraldi@gmail.com
}

Keywords Geoheritage · Geosites · Web mapping · Inventories

\section{Introduction}

Due to the renewed interest for sites of geological interest (Burek and Prosser 2008; Reynard et al. 2011), both in nature conservation (Gray 2004) and tourist sectors (Dowling and Newsome 2006, Megerle 2008), numerous regional and national geosite inventories have been carried out in several countries during the last two decades.

For this purpose, various assessment methods have been developed and published (for a review, see Reynard et al. 2009), and several countries or regional boards have published guidelines for geosite inventories (see for example De Wever et al. 2006 in France). The question of how to represent the results of inventories is much less studied and remains open. In particular, two main questions need to be addressed: (1) Which mapping system should be used to present the results to the different types of potential users (especially practitioners, tourists and students)? (2) The issue of updating data, if we consider that an inventory is not static but should be updated when new sites are discovered and when a site changes. Geographical information systems (GIS) seem to be ideal for both requirements (representation, updating). Nevertheless, if in the field of nature conservation, people are used to working with GIS, it is not the case in the tourist sector where data must be delivered to the users in openaccess and easy-to-use formats.

Web mapping (Kraak and Brown 2001) - that is, the process of implementing and visualising maps on the World Wide Web-seems to be a particularly suitable tool to achieve the two objectives (visualisation and updating). Web mapping facilities are now beginning to be widely used for storing and visualising geological and geomorphological data by 
geological and cartographic national surveys (see, for example, the OneGeology initiative (www.onegeology.org) that is a common project of geological surveys around the world to make dynamic geological maps available on the web or the US Geoscience Information Portal (www.usgin.org) that develops open-source applications to share geoscience data).

In the area of geoheritage studies, GIS and web mapping technologies have already been used in various fields including digital field mapping (e.g. Ghiraldi et al. 2010; Gallerini et al. 2011), geoheritage data visualisation on open-source interfaces (e.g. Suma and De Cosmo 2011; Gallerini et al. 2011; Martin and Ghiraldi 2011) and virtual field trips (Cayla et al. 2012). To obtain a usable web map, the design should be adapted not only to the user's preferences and needs but also to efficiently and easily provide the requested information. Third generation mobile telephones constitute an infrastructure with a strong potential for geosite interpretation and promotion. They combine the necessary operative system (Android or iOS) with GPS georeferencing and Internet connection, which offers a wide range of opportunities such as location-based information (Dias et al. 2004, Barisic 2011), QR-codes (Frey and Hinkelmann 2009) or multimedia content. Routes in natural areas with information that can be downloaded for their use on site are now proposed (e.g. Castilla y León (Spain), www.icairn.org). Nevertheless, such information is still very scarce and focuses on how to follow the route. Moreover, working as a community-as it is sometimes the case-increases the potential not only of knowledge addition but also of incorrect information being uploaded.

In this paper, we present an application developed for visualising data from the inventory of Swiss geosites. Because of the federal organisation of the country, nature conservation in Switzerland is mainly a task of the Cantons (regional authorities). It was only at the beginning of the 1990s that a national inventory was initiated by the Swiss Academy of Natural Sciences. The results of this first inventory were published in 1999 (SAS 1999) as a list of sites with descriptive attributes. The inventory was not in a digital form, and in the map of Swiss geosites that was produced, each site was simply presented as a dot, without any perimeter. A revision of the list was initiated in 2006. Several tasks were carried out, including the elaboration of a digital database, the addition of missing attributes in the database, the addition of several sites and the removal of others, and the scanning of each site perimeters (Reynard, 2012). This work was carried out by a group of Earth scientists from various parts of Switzerland (Reynard et al. 2012). The final list, including 322 sites, was published in December 2012, and all the data are stored in the Swiss geosite database, hosted by the Swiss Academy of Natural Sciences.
In this paper, we present and discuss a web mapping application that was developed to allow the results of the inventory to be visualised.

\section{A Web Mapping Tool for Geosite Inventory Visualisation}

\section{Data and Structure}

There are presently many web mapping applications. Google Maps application programming interface (API) was selected for this project because it is well documented and can be freely modified. The project could have been developed with other open-source equivalents like OpenLayers.

The application uses two sets of data (see Martin and Ghiraldi 2011 for more details): the basemap layers are directly taken from Google servers, and other data are stored on a local server (http://mesoscaphe.unil.ch/geodata/geosites2/) (Fig. 1). These include KML files (perimeters, photos, figures etc., downloaded from the Swiss geosite database) and a MySQL single table database to store all the geosite attributes (109 attributes downloaded from the Swiss geosite database, from which only 20 are currently activated in the application). Other secondary data (limits of Cantons, surfaces of natural sites from other inventories) are stored as KML files. As the application is quite completely dynamic (except for KML files), it is easy to update or to be implemented with other data, and it is to note that the geosite perimeters are not redrawn from Google maps, but directly imported from the Swiss geosite database.

\section{Navigation and Selection Functions}

The window is divided in two parts: the map (with specific navigation tools) and a search panel divided into four sections (Fig. 2). The user interface gives a large place to the map, for data presentation and exploration. As usual, in web mapping applications, the map can be paned and zoomed, and the basemap can be changed (map, aerial photography, relief and Google Earth). A special tool has been added to zoom on defined regions (Cantons) or search for places (Figs. 2 and 3).

Right of the map, a side column contains four sliding panels that allow different actions according to the user's aims. With the first panel, a specific geosite can be searched (by its name or code), and an interactive legend shows on demand only geosites from a specific type (geological, geomorphological or speleological) (Fig. 2). The second panel is a multi-criteria query builder. For example, one can look for geosites of hydrogeological and speleological interest, or that are active and natural. As with the first panels, results are shown on the map with coloured markers. The user can choose to also display the corresponding surface and 
Fig. 1 Structure of the web mapping project

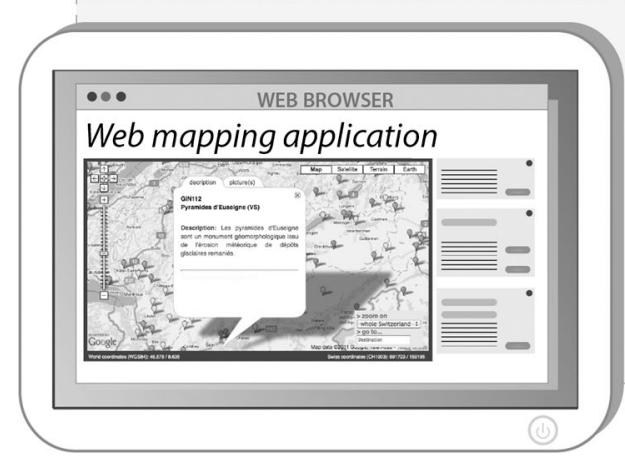

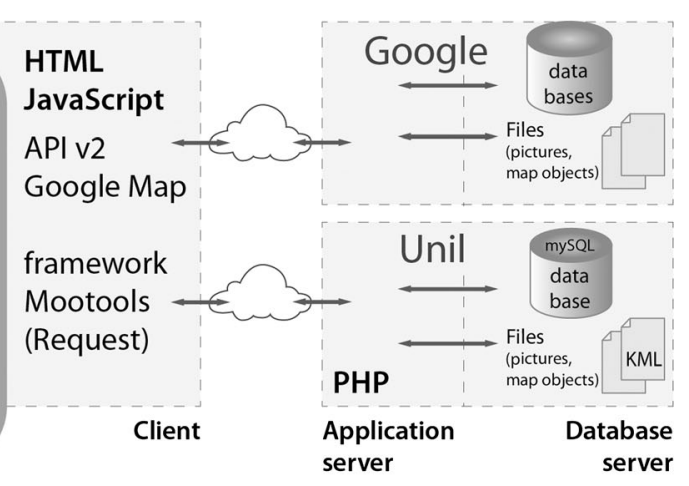

perimeters. The third panel allows additional layers to be loaded, like the inventory of landscape of national significance or geological maps; this panel could also serve to load the user's own data. A fourth panel allows the visualisation of additional data for specific selected sites (see "From Global to Local Scale").

\section{From Global to Local Scale}

The Swiss geosite inventory is a national project. It was decided to reduce spatial information on specific geosites to the perimeter and the surface of the site. For large and complex geosites, like geomorphological systems including several different objects (e.g. proglacial margins, complex karstic sites etc.), there is, therefore, an important loss of information. For this reason, we have conducted an experiment on the integration of local scale data to the map. The objective is to give an accurate impression on what the visitor is going to find in the geosite. Four geosites situated in the Canton of Vaud were selected based on the fact that they offer different interests and extensions (Fig. 3): (1) The Col de la Croix is a quite small geosite located in a mountain pass, where a gypsum outcrop has led to the creation of erosion karstic landscape with pyramids and dolines; (2) the Veveyse de Fégire is a gorge excavated by a river on the glacial sediments of the Rhône glacier, north of Geneva Lake, as a result of fluvial capture, with abundant examples of gravitational processes due to the deep incision on till deposits; (3) the Moraine landscape of Lausanne geosite is an "urban" geosite comprising all landforms that comprise the Lausanne relief; and (4) the geosite called Haut Jura anticline valleys is a typical folded Jura landscape with a large variety of structural and karstic landforms.

Col de la Croix, Veveyse de Fégire and Haut Jura anticline valleys are geosites of national significance included in the Swiss inventory, whereas Moraine landscape of Lausanne is a geosite of regional importance included in the geosite inventory of Vaud Canton, published in 2008.

For all of these sites, more data are added in the database, specifically a simple geomorphological map, brief texts explaining the main features of the geosite and its morphogenesis; relevant sketches such as geological and
Fig. 2 A view of the web mapping project window. Left map. A scrolling tool allows the sites to be visualised by Canton and a tool (go to...) allows the user to search a site directly. Right attributes. Four panels allow a search for the sites or a selection of the sites according to several criteria (in this example, the geomorphological sites are viewed on the Swiss Tectonic Map layer and relief basemap)

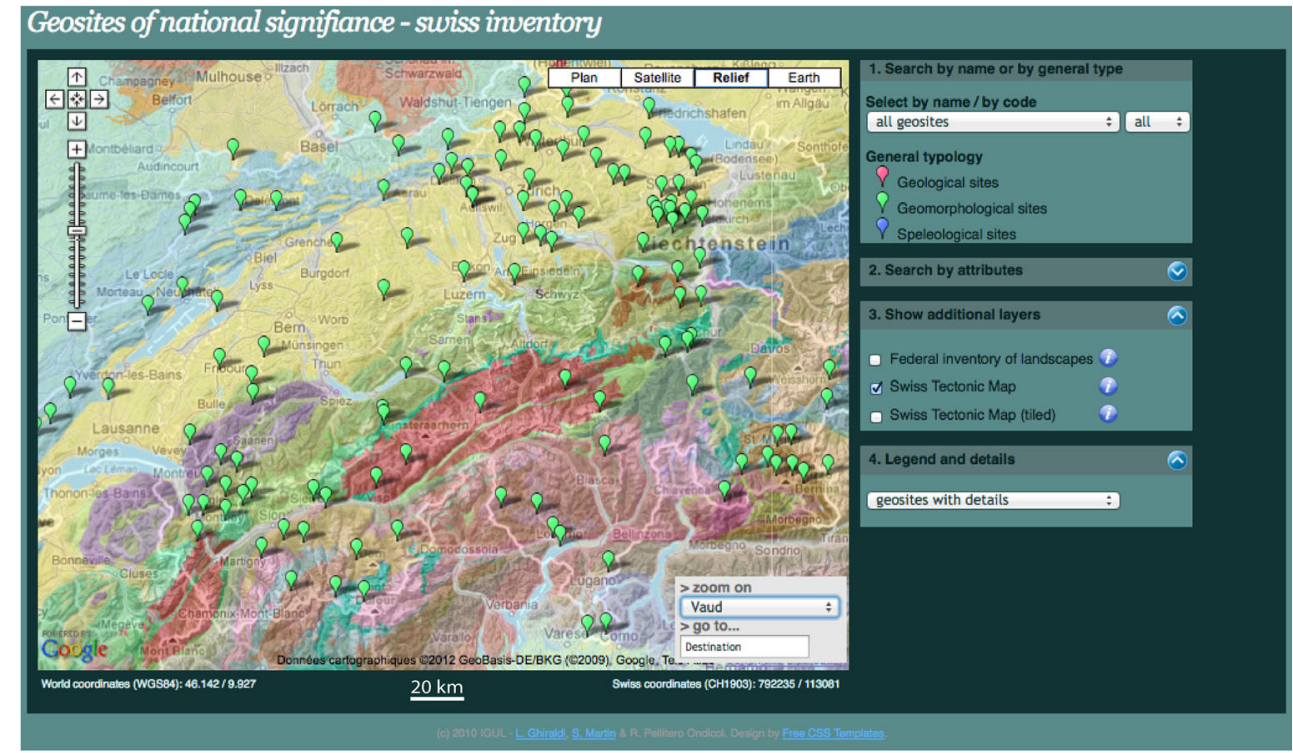


Fig. 3 A view of the zoom of the Vaud Canton. On the right side, the "Legend and details" section allows the selection of specific geosites for which additional data have been included in the database

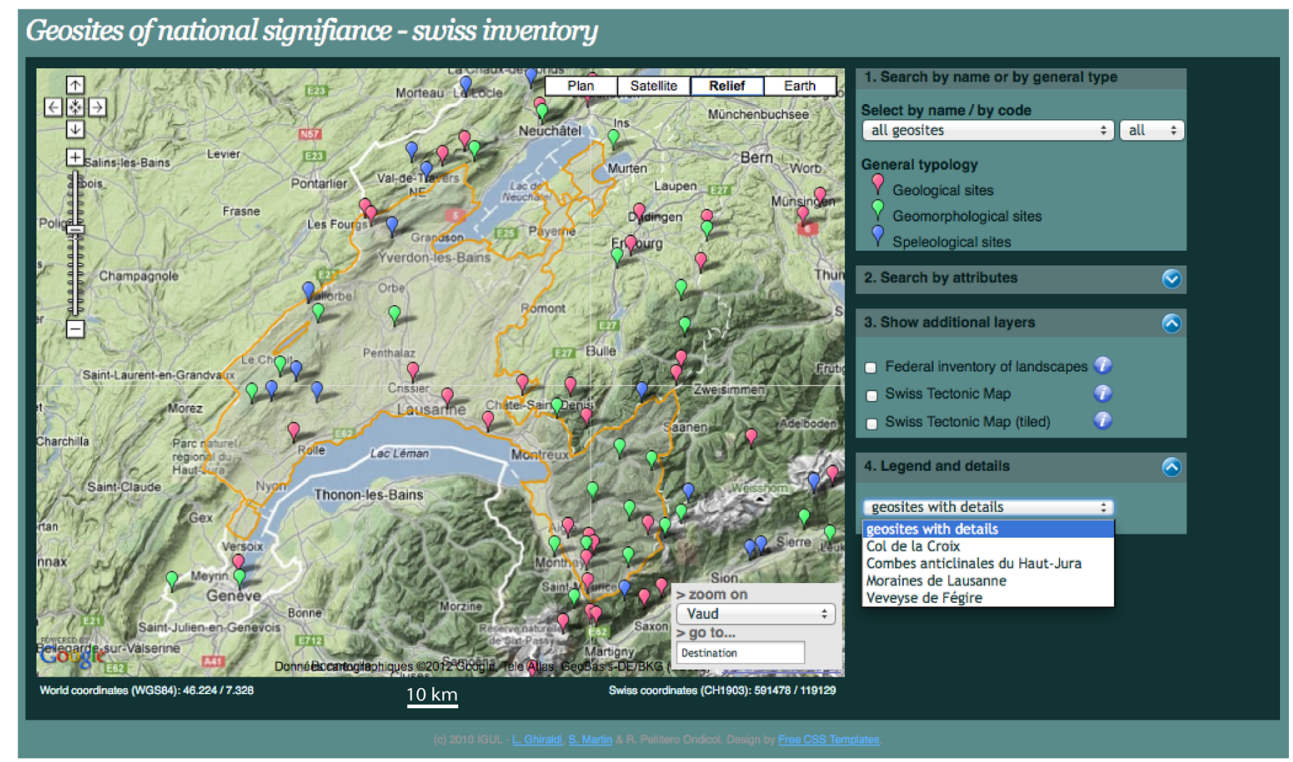

sedimentological profiles, evolution of landforms and images (Table 1). Text is added in html format and images and sketches in .jpg format. The geomorphological map was designed according to the Lausanne University chart (Schoeneich et al. 1998) through Quantum GIS, and it was transformed to KML format to conform to Google Maps API. For this reason, it was necessary to add a new section to the menu, called "legend and details", which connects the user request to a SQL database and this database to KML features, so that they are shown on the map. It must be stressed that the legend was designed to be interactive, so that the user can choose which data are shown and which are not. KML file format has some limitations for design. Lines and polygons can only be plain coloured, with no patterns, but transparency can be added. On the other hand, text, hypertext and images can be added as additional information, which will open when clicking on the feature.

Because of the Col de Croix small extension, the geomorphological map was not of much use. It was, therefore, marked as a dot, and additional data (surrounding lithology, geological profile) is offered. Some explanatory sketches about the formation and evolution of the site were added. The Veveyse de Fégire and the Moraine landscape of Lausanne are very different geosites due to their natural and urban environment, respectively. Nevertheless, they have similar extensions (Table 1), so that data treatment can be the same. A simplified geomorphological map on 1:25,000 scale was designed, and explanations can be found for each form, related to an "information dot" situated within the form (Figs. 4 and 5). Finally, the Haut Jura anticline valleys are quite an extended geosite, so we decided to focus the information on some points along a hiking route that covers the most interesting places within the site. The four different basemaps allow the user to select the best possibility to visualise the landforms (see the differences in Figs. 4, 5 and 6). The navigation tools of Google Earth are particularly adapted for the representation of landforms (e.g. landslides on Fig. 6).

\section{Discussion}

Mapping Interests and Limitations

Cartography is the most ancient and the most widely used means of communication to obtain information about a territory. Geoscientists and managers as well as amateurs need to use these kinds of information easily and immediately. With the development of the Web, the way of accessing information

Table 1 Geosite local information added to the Swiss inventory

\begin{tabular}{llll}
\hline Geosite & Extension $\left(\mathrm{km}^{2}\right)$ & Geomorphological mapping & Additional information \\
\hline Col de la Croix & 0.15 & Point & Images, text, explanatory sketches and geological profile \\
Veveyse de Fégire & 5.78 & Lines and polygons & Images, text, explanatory sketches and sedimentological profiles \\
Lausanne morainic ridges & 23.68 & Lines and polygons & Images and text \\
Anticlinal valley of Haut Jura & 47.39 & No map & Hiking route, images and text \\
\hline
\end{tabular}


Fig. 4 Zoom of the Veveyse de Fégire geosite on the relief basemap. A simplified geomorphological map has been produced using the University of Lausanne Geographical Institute chart (Schoeneich et al. 1998); each landform can be selected individually (see the right panel). On the map, information dots allow additional information, like a description of the landforms and pictures, to be shown

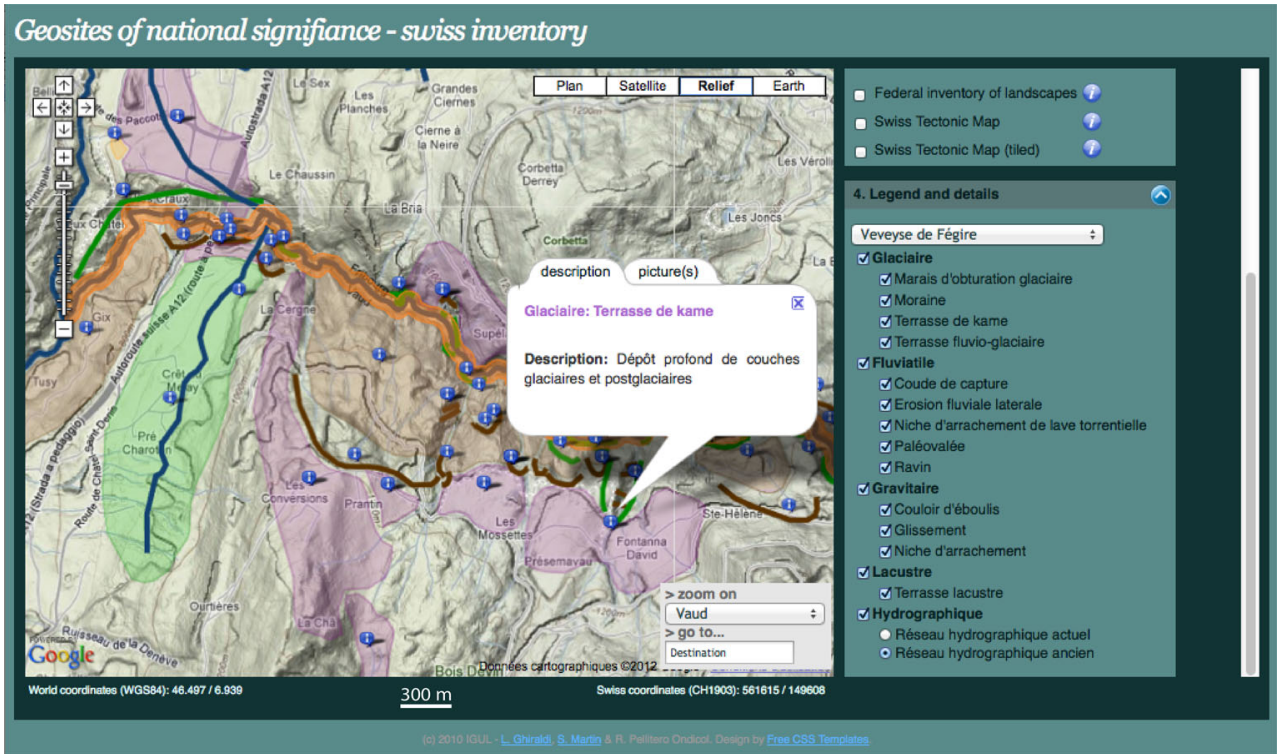

has radically changed. Cartography may now be considered as an informing tool intended for a wider audience. Dynamism, usability and interactivity are the keywords. This implies its use in the following manner:

1. Tools allowing the users to edit, update, replace and add items in real time;

2. Tools in which the information is presented in a clear and concise way, without requiring any specialised training; and last but not least,

3. Tools able to perform some thematic and spatial selections, where the maps are dynamically created and generated rapidly by the users, through the use of functions allowing the ability to change the map's extent, toggle map layers on/off, obtain detailed information through specific query, browse to web sites associated with map features through hypertext and explore data patterns and relationships using visualisation tools that are dynamically linked to the map.

Web mapping mainly differs from printed maps because it allows the user to interact with the content and process of encoding. Data, semiology and scale can be adapted to the needs of the user and, in some cases, by the user themselves. More specifically, Google Maps and Google Earth provide an attractive framework due to 3D vision potential, downscaling
Fig. 5 Zoom of the Veveyse de Fégire geosite viewed on aerial photography. Information dots allow geomorphological sketches describing the landform morphogenesis to be shown

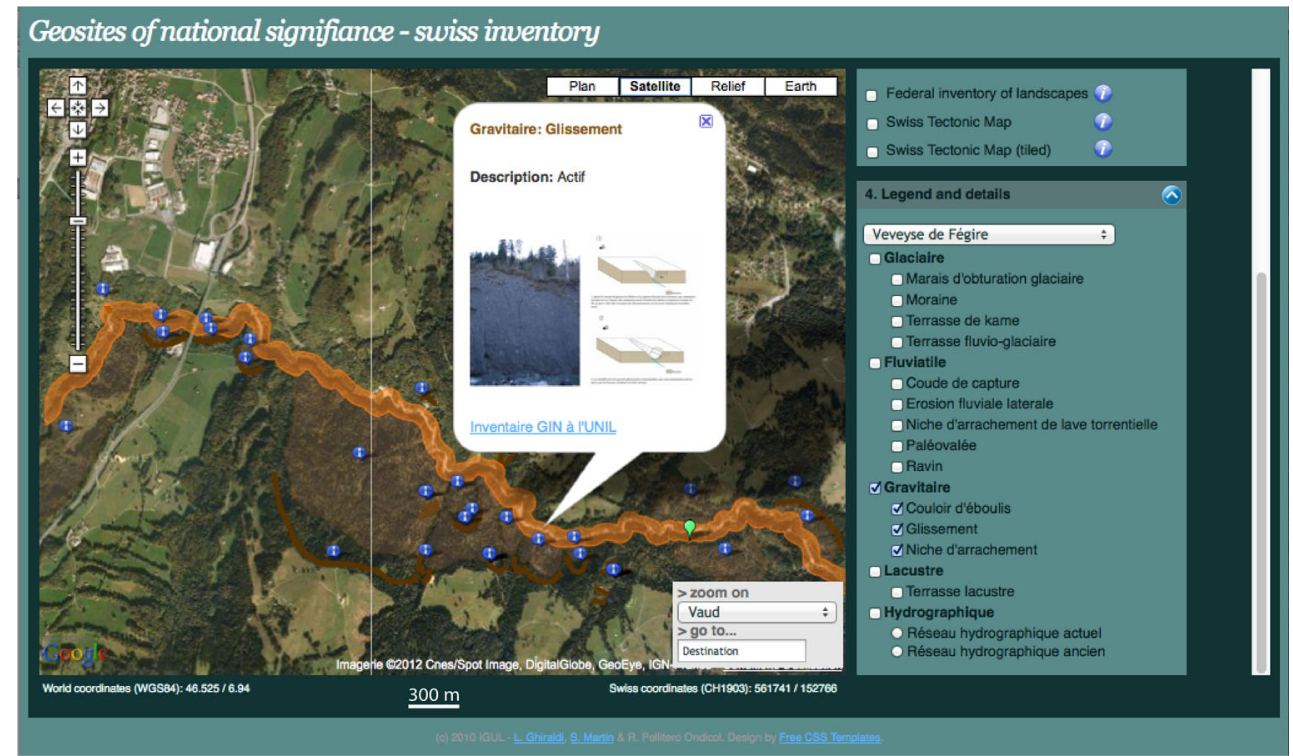


Fig. 6 Zoom of the Veveyse de Fégire geosite viewed on the Google Earth basemap. The navigation tools of Google Earth allow a very realistic visualisation of landforms (here, landslides)

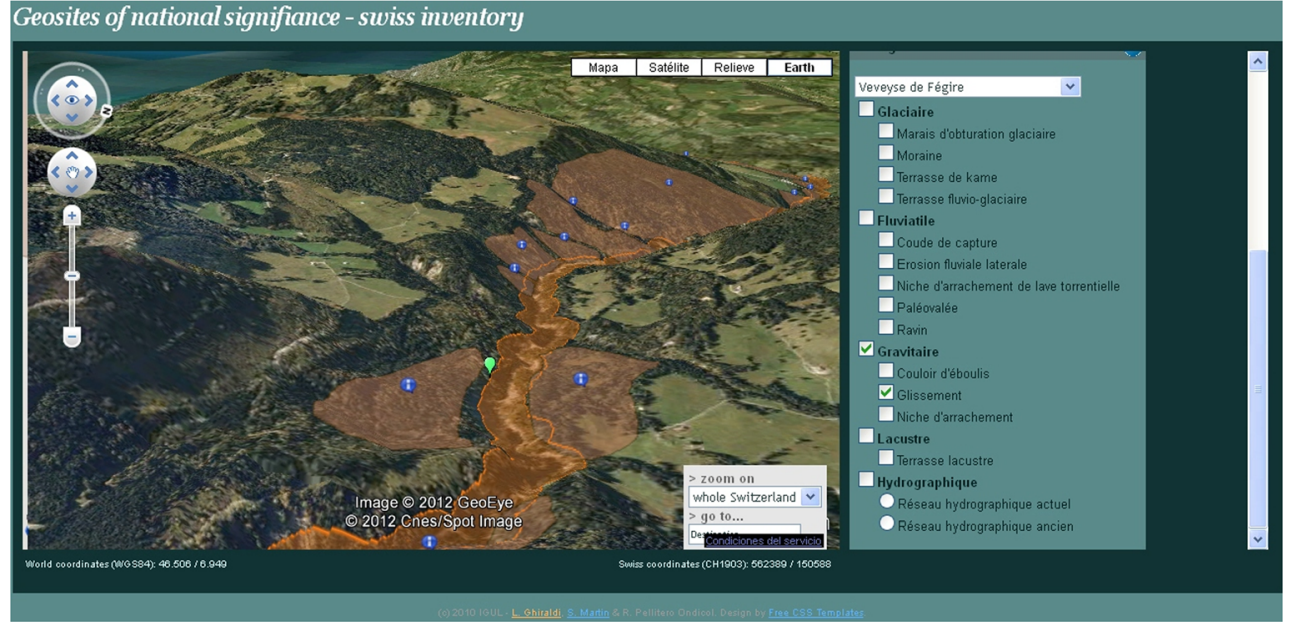

and up-scaling easy navigation and widespread use among the various users. The online geosite inventory map presented in this paper shows how an interactive legend and multiselection tools can produce a wide variety of potential or virtual maps as described by Muller and Laurini (1997). It is also an attempt to apply multi-scale navigation not only to data representation (for example, the dimension of the markers shown on the screen) but also to the data. Moreover, the application is not restricted to one type of user; it allows the information to be composed with different levels of complexity.

At the local scale, the inventory map becomes a simplified geomorphological map, and the legend changes accordingly. In spite of limited cartographic tools available, the results are quite promising. Geomorphological maps draped on Google Earth 3D relief give the reader a different view on landscape interpretation, as shown in Fig. 6. Moreover, additional information can help to explain geosites (Fig. 4), and interactive tools allow the user to use several sources of information simultaneously.

Nevertheless, several limitations must be stressed. Firstly, KML format is not flexible enough to add interactive information; other formats or platforms should be tested. Secondly, it is necessary to decide a previous scale of approach before web map development, which is related to the geosite extension. It is also desirable to know the targeted user's previous knowledge, in order to adapt the information to their needs and desires. Thirdly, users cannot introduce their own data.

\section{Web Maps as a Management Tool}

Smith et al. (2011) demonstrated how mapping can help with geosite management. In that case, the interpretation was focused on landslides. The initial idea was to create a simple slope instability map, which could become a decision-support tool for stakeholders and managers (mostly National Trust in this case). Soon, authors became aware of the misconceptions of non-specialists on slope failures; therefore, images and explanations were added to the map (see "interactive maps" on http://www.qub.ac.uk/geomaterials/weathering/causeway/ index.php, consulted 19/06/2012). Nevertheless, in this case, maps are only available for interpretation on the web as pure images, and not real interactive maps. The application proposed here could be used to help site management, e.g. by adding data on landform activity not only at the country scale (Fig. 2) but also at the geosite scale (Fig. 6). It could also be oriented to geodiversity recognition and quantification, as was proposed by Suma and de Cosmo (2011).

As geosite management is usually part of a wider landscape or park management, the development of web mapping tools should be coordinated with all the different data users. In particular, as shown in this paper, integration of data from other nature sciences inventories (e.g. inventories of biotopes or landscapes, as shown on Fig. 2) helps integrative management of the various values of specific sites. This is particularly important for ensuring a better recognition of the importance of geosites by nature conservation managers that sometimes do not know of the presence of geosites in the areas they are in charge of (Fontana and Reynard 2012). An example is the web map, developed on Google Maps API, recently proposed by Bosson and Reynard (2012), to improve the geomorphological heritage recognition in the Contamines-Montjoie Natural Reserve (Mont-Blanc massif, Northern Alps, France) (see the application on http://mesoscaphe.unil.ch/ geovis_igul/gm_contamines/).

Finally, we consider that interactive web maps can help the inventory process itself. Collaborative work is an already classic use of web maps (MacEachren 2001, MacEachren and Kraak 2001). In our case, the revision of the Swiss inventory was carried out over a period of 6 years, with the participation of more than 20 experts coming from various parts of Switzerland. The web database allowed the various personnel involved to enter the data directly in real time. The interactive web map allowed them to visualise the evolution of 
the inventory during the inventory-construction period. The map is, therefore, a tool that improves interactivity between the various experts. Now that the project is concluded, it will be a tool for disseminating the results to a wide audience.

\section{Web Map to Support Site Interpretation}

A geosite inventory is not only a tool for nature conservation practitioners but also a base for the dissemination of knowledge on geoheritage to a wider public (schools, tourists etc.). Two challenges arise when trying to use web mapping as a site interpretation tool: cartographic issues and user issues.

Web mapping programmes generally offer very poor graphical tools for data representation. This is a strong limitation for geological or geomorphological mapping, as it is also partially the case with desktop GIS applications. The cartographer sometimes has to reconsider the legend of the map and the structure of data, taking into account that interpretive maps certainly do not necessitate as many categories and details as true geological or geomorphological maps. This was the case in this project. The geomorphological maps had to be simplified for technical reasons (impossibility of using graphics), but on the other hand, the interactive 3D-representation tools proposed by Google Earth allowed a "plastic" representation of landforms (Fig. 6), much more understandable by nonspecialists than the graphics usually used on classical geomorphological maps.

Interpretation is "a mission-based communication process" (NAI 2011). Therefore, target audience becomes a central issue for every interpretive media (Martin et al. 2010). What the user should know, what he believes, what he sees or recognises (Crawford and Black 2012; Regolini and Martin 2012) and what he is interested in (Pralong 2003; Martin 2013) should be taken into account. This is, of course, essential not only for map content (data, features, legend) but also for the web mapping application. Geotourist maps are usually quite poor at meeting users' needs, especially with helping to interpret features (Regolini 2012). The potential of information available in web maps can overcome this shortcoming. Site interpretation should start with the easiest features to find or understand and guide users on discovering less visible features (Regolini 2012: Regolini and Martin 2012). This is the case in the proposed application that allows the user to distinguish and visualise each landform individually (e.g. Fig. 6 presents only landslides). In this way, the user can understand what the main processes active in the considered area are, and how they interact spatially. Nevertheless, in this application, we have not developed a real guide that organises the available information and the user's visit.

\section{Discussion, Conclusions and Prognoses}

This paper proposes a web mapping application to visualise the results of geosite inventories. The application was developed in Google Maps API that has the double advantage of being open source and proposes easy-to-use and high-quality basemaps all over the world, and easily accessible on Google servers. Only the specific data related to the geosite inventories are stored on a local server. Data updating is easy to implement, selection and search tools have been implemented and allow easy navigation of the database and visualisation of the selected objects on the map. Tools have also been developed to add specific information, increasing, therefore, the available information at the local scale. A dynamic simplified geomorphological map allows the user to differentiate the various landforms that compose the considered geosite. The next steps of the project will be to propose tools that not only allow the various landforms to be distinguished - with specific information-but also allow the temporal evolution of landforms to be shown or propose virtual visits. Indeed, web mapping tools could probably provide substantial advantages for heritage promotion and geoconservation. We can imagine an application collecting visitors' own appreciation of geosites, as a complementary assessment of certain values, such as aesthetic, tourist or sentimental values. Such a tool could help to fill the gap between specialists and nonspecialists, thus widening the legitimacy of a geosite inventory and involving non-specialists in geoheritage recognition and conservation.

In the future, the tool will also be used for the promotion of the inventory of Swiss geosites. The application is stored on the University of Lausanne website, but links will be made with the Swiss Academy of Sciences website. One open question remains: Google Maps API is an interesting, easyto-use and free-of-charge tool for disseminating information about geoheritage, but there is also the risk that the data produced by the scientists are appropriated by Google and, as such, compromising intellectual property. At the moment, we consider this risk to be lower than the potential offered by the tool.

Acknowledgments The authors wish to thank the anonymous referees, José Brilha and the editors of the journal, whose suggestions helped to improve the manuscript. The Swiss Academy of Sciences (SCNAT) is also thanked for allowing us to use the data of the inventory of Swiss geosites.

\section{References}

Barisic M (2011) Camineo. Solutions for tourism and nature discovery. International Symposium on Geosite Management, Intensive course, Evian 
Bosson JB, Reynard E (2012) Geomorphological heritage, conservation and promotion in high-alpine protected areas, eco.mont 4(1): 5-14

Burek CV, Prosser CD (2008) The history of geoconservation. The Geological Society, London

Cayla N, Hoblea F, Guasquet D (2012) Place de la géomorphologie dans l'offre géotouristique de l'arc alpin : du réel au virtuel. In: Giusti C (ed) Raising the profile of geomorphological heritage through iconography, inventory and promotion. University Paris Sorbonne, Paris, pp 65-71, Proceedings Volume

Crawford KR, Black R (2012) Visitor understanding of the geodiversity and the geoconservation value of the Giant's causeway world heritage site, northern Ireland. Geoheritage 4:115-126

De Wever P, Le Néchet Y, Cornée A (2006) Vade-mecum pour l'inventaire du patrimoine géologique national. Mémoire hors série de la Société géologique de France 12

Dias ES, Rhin C, Haller R, Scholten H (2004) Adding value and improving processes using location-based services in protected areas. In: Prastacos P, Cortes U, de Leon JLD, Murillo M, e-Environment: progress and challenge (eds) The WebPark experience. Instituto Politécnico Nacional Mexico, Mexico, pp 291-302

Dowling R, Newsome D (2006) Geotourism. Elsevier, Oxford

Fontana G, Reynard E (2012) La gestion du patrimoine géologique dans les parcs naturels en Suisse. In: Giusti C (ed) Raising the profile of geomorphological heritage through iconography, inventory and promotion. University Paris Sorbonne, Paris, pp 133-139, Proceedings Volume

Frey ML, Hinkelmann K (2009) Application of innovative technology QR-code for popularisation of Earth heritage topics at the World heritage site Messel Pit, Germany. In: Bayerisches Landesamt für Umwelt (ed), 6th European Congress on Regional Geoscientific Cartography and Information Systems. Earth and Man (vol. 2), Landesamt für Vermessung und Geoinformation, München, pp 250-253

Gallerini G, Susini S, Bruciatelli L, De Donatis M. (2011) Geomatics and geo-tourism: San Bartolo Natural Park case study (Pesaro, Italy). In: Geology of the Adriatic area. GeoActa, Special Publication 3:167178

Ghiraldi L, Coratza P, Marchetti M, Giardino M (2010) GIS and geomatics for the evaluation and exploitation of Piemonte geomorphosites. In: Regolini-Bissig G, Reynard E (eds), Mapping Geoheritage. Institut de géographie, Lausanne, (Géovisions 35), pp $97-113$

Gray M (2004) Geodiversity. Valuing and conserving abiotic nature. Wiley, Chichester

Kraak MJ, Brown A (2001) Web cartography—developments and prospects. Taylor and Francis, New York

MacEachren AM (2001) Cartography and GIS. Extending collaborative tools to support virtual teams. Prog Hum Geogr 25:431-444

MacEachren AM, Kraak MJ (2001) Research challenges in geovisualization. Cartogr Geogr Inf Sci 28(1):3-12

Martin S (2013) Quel intérêt pour le géotourisme? Résultats d'une enquête auprès des visiteurs de trois sites des Alpes suisses. In: Hobléa F, Cayla N, Reynard E (eds) Gestion des géosites dans les espaces protégés. Collection EDYTEM 15, Chambéry, pp 95-101
Martin S, Ghiraldi L (2011) Internet au service du patrimoine. Cartographie dynamique de l'inventaire des géotopes d'importance nationale. In: Reynard E, Laigre L, Kramar N (eds) Les géosciences au service de la société. Institut de géographie, Lausanne, (Géovisions 37), pp 105-117

Martin S, Regolini-Bissig G, Perret A, Kozlik L (2010) Élaboration et évaluation de produits géotouristiques. Propositions méthodologiques. Téoros 29(2):55-66

Megerle H (2008) (Hrsg.) Geotourismus. Innovative Ansätze zur touristischen Inwertsetzung und nachhaltigen Regionalentwicklung. Kersting, Rottenburg am Neckar

Muller JM, Laurini R (1997) La cartographie de l'an 2000. Revue internationale de géomatique 7(1):97-106

NAI (2011) National Association for Interpretation. Mission, vision, and core values. http://www.interpnet.com/about_nai/mission.shtml (retrieved 30/11/2011)

Pralong JP (2003) Valorisation et vulgarisation des sciences de la Terre. Les concepts de temps et d'espace et leur application à la randonnée pédestre. In: Reynard E, Holzmann C, Guex D, Summermatter N (eds) Géomorphologie et tourisme. Institut de géographie, Lausanne, (Travaux et Recherches 24), pp 115-127

Regolini G (2012) Cartographier les géomorphosites : objectifs, publics et propositions méthodologiques. $\mathrm{PhD}$ Thesis. Institut de Géographie, Université de Lausanne

Regolini G, Martin S (2012) Bâtir la médiation sur ce qui est vu. Une première approche de la perception des formes du relief alpin par les non-spécialistes. Géocarrefour 87(3-4):199-210

Reynard E (2012) Geoheritage protection and promotion in Switzerland. European Geologist 34:44-47

Reynard E, Coratza P, Regolini-Bissig G (2009) (eds) Geomorphosites. Pfeil, München.

Reynard E, Hobléa F, Cayla N, Gauchon C (2011) Iconic sites for Alpine geology and geomorphology. Rediscovering heritage? Revue de géographie alpine, 99(2). [en ligne], mis en ligne le 20 juillet 2011. http://rga.revues.org/index1435.html (retrieved 13/12/2012)

Reynard E, Berger JP, Constandache M, Felber M, Grangier L, Häuselmann P, Jeannin PY, Martin S (2012) Révision de l'inventaire des géotopes suisses : rapport final. Groupe de travail pour les géotopes en Suisse, Berne.

SAS (1999) Inventory of Geotopes of national significance. Geol Insubr 4(1):31-48

Schoeneich P, Reynard E, Pierrehumbert G (1998) Geomorphological mapping in the swiss alps and Prealps. In: Kriz K (ed) Hochgebirgskartographie Silvretta, workshop der Kommission Hochgebirgskartographie der deutsche Gesellschaft für Kartographie. Wiener Schriften zur Geographie und Kartographie. Institut für Geographie der Universität Wien, Wien, pp 145-153

Smith BJ, Pellitero R, Alexander G (2011) Mapping slope instability at the Giant's causeway and causeway coast world heritage site: implications for site management. Geoheritage 3:253-266

Suma A, de Cosmo PD (2011) GeoDiv interface: an open source tool for management and promotion of the geodiversity of sierra de Grazalema natural park (Andalusia, Spain). GeoJournal of Tourism and Geosites 8(2):309-318 